\title{
Red Reflex Test
}

National Cancer Institute

\section{Source}

National Cancer Institute. Red Reflex Test. NCI Thesaurus. Code C81283.

An optic examination in which an ophthalmoscope or retinoscope is placed approximately

$30 \mathrm{~cm}$ from the eye to visualize whether a reddish hue is reflected from the retina. 